\title{
Minimum Volume Standards in Surgery - Are We There Yet?
}

\author{
Hartwig Bauera Kim C. Honselmann $^{b, c}$ \\ a Neuötting, Germany; \\ ${ }^{b}$ Department of Surgery, University Medical Center Schleswig-Holstein, Campus Lübeck, Lübeck, Germany; \\ ${ }^{c}$ Andrew L. Warshaw, MD Institute for Pancreatic Cancer Research, Thier 623, Department of Surgery, Massachusetts General Hospital, \\ Boston, MA, USA
}

\section{Keywords}

Surgery · Volume-outcome relationships · Minimum volume standards - Minimum quantity regulations .

Failure to rescue $\cdot$ Center formation - Certification criteria

\section{Summary}

The quality of surgery is directly dependent on the quantity, more specifically, on the number of operations performed at a given hospital as well as on the designated surgeon. This fact is supported by numerous studies and meta-analyses that will be presented in the following text. Most of the convincing data for complex procedures can be obtained from visceral (upper and lower gastrointestinal) surgery studies. Mortality of large oncological procedures, such as esophageal or pancreatic surgery, can be reduced by $50 \%$ if a certain number of interventions are guaranteed per year. Centralizing these operations performed by specialized surgeons is the key to success. This also ensures that the minimum volume amounts within a given hospital are well above the required levels, thus enabling to teach the necessary expertise step by step. The obligatory 'learning curve' for complex interventions cannot be completed within the framework of reference figures during residency training. Together, surgeons and their respective societies have introduced a proposal for efficient case-oriented centralized surgery. Whether 'we are there yet' in surgery will depend in the end on how these efforts will be incorporated into administrative requirements and the guidelines that will then be implemented across the board.

(C) 2017 S. Karger GmbH, Freiburg

Abridged and translated version of chapter 8 by Prof. Hartwig Bauer in Klauber J, Geraedts M, Friedrich J, Wasem J: Krankenhaus-Report 2017. Schwerpunkt: Zukunft gestalten. 1/e Stuttgart, Schattauer 2017; pp 107-131.

\section{Introduction}

For 12 years, there has been a minimum quantity regulation (Mm-R) in Germany for certain elective services. Many hospitals still fail to meet these targets and still maintain their patient care offer in this area. However, mortality in hospitals that do not comply with the Mm-R is clearly higher; a strict implementation of the $\mathrm{Mm}-\mathrm{R}$ and a further specialization of hospitals for certain elective interventions could clearly improve quality of care with fewer complications and deaths $[1,2]$. The question posed in the title would therefore be clearly rejected. In order to illustrate further need for action, the following points will be addressed in the following literature with reference to scientific data:

- Volume-outcome relationships in surgery

- Surgical oncology

- Bariatric surgery

- Volume-outcome relationships in other procedures

- Minimum volume standards in residency (education in surgery)

- Operation catalogs with reference numbers as minimum numbers

- Surgery is more than operating

- Minimum quantity regulation pursuant to $₫ 136 \mathrm{~b}$ paragraph 1 sentence 1 no. 2 SGB V

- 'Failure to rescue': The handling of complications is important

- Specialization and center formation

- Certification criteria for surgical societies

- Competence Center, Reference Center, and Center of Excellence

- Conclusion

\section{Volume-Outcome Relationships in Surgery}

A link between high volume and good quality is empirically well documented. Luft et al. [3] set up a 'volume-outcome hypothesis'

\section{KARGER}

() 2017 S. Karger GmbH, Freiburg

Fax +497614520714 
Fig. 1. Risk-adjusted 30-day mortality in relation to the incidence of esophageal resections (6,337 patients, 1,575 hospitals, $\mathrm{p}<$ $0.001)$ and pancreatic resections (10,530 patients / 1,868 hospitals $\mathrm{p}<0.001$ ) (modified from [4]).
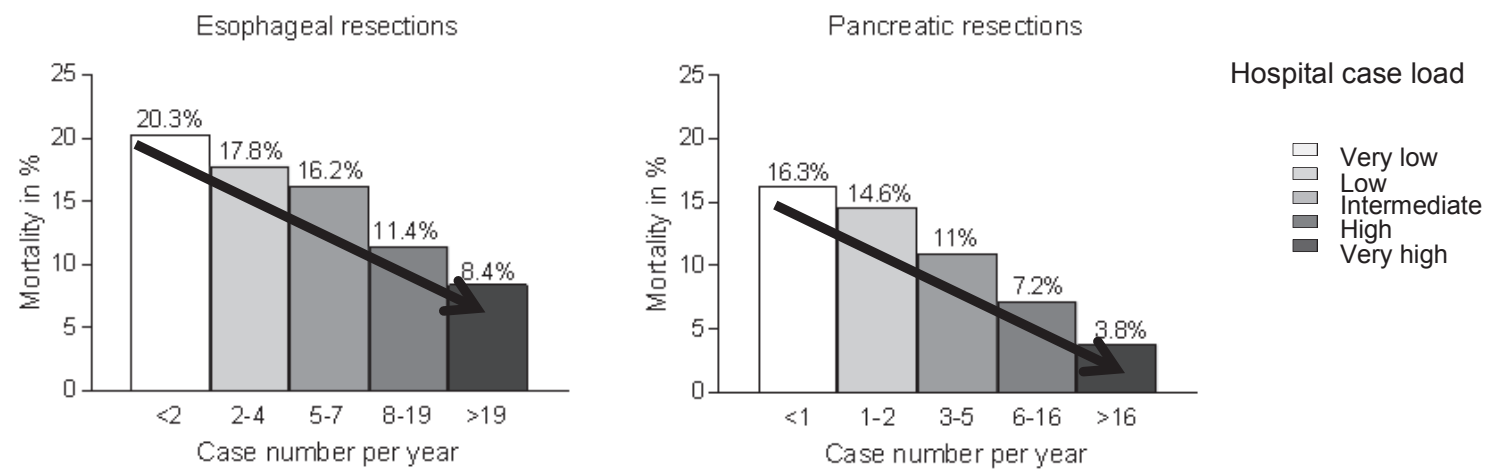

Fig. 2. Significantly lower readmission rates within 30 days postoperatively in high-volume versus low-volume hospitals (aortocoronary bypass, lung resection, abdominal aortic aneurysm endovascular and open, colon resection, hip replacement) (modified from [15]).

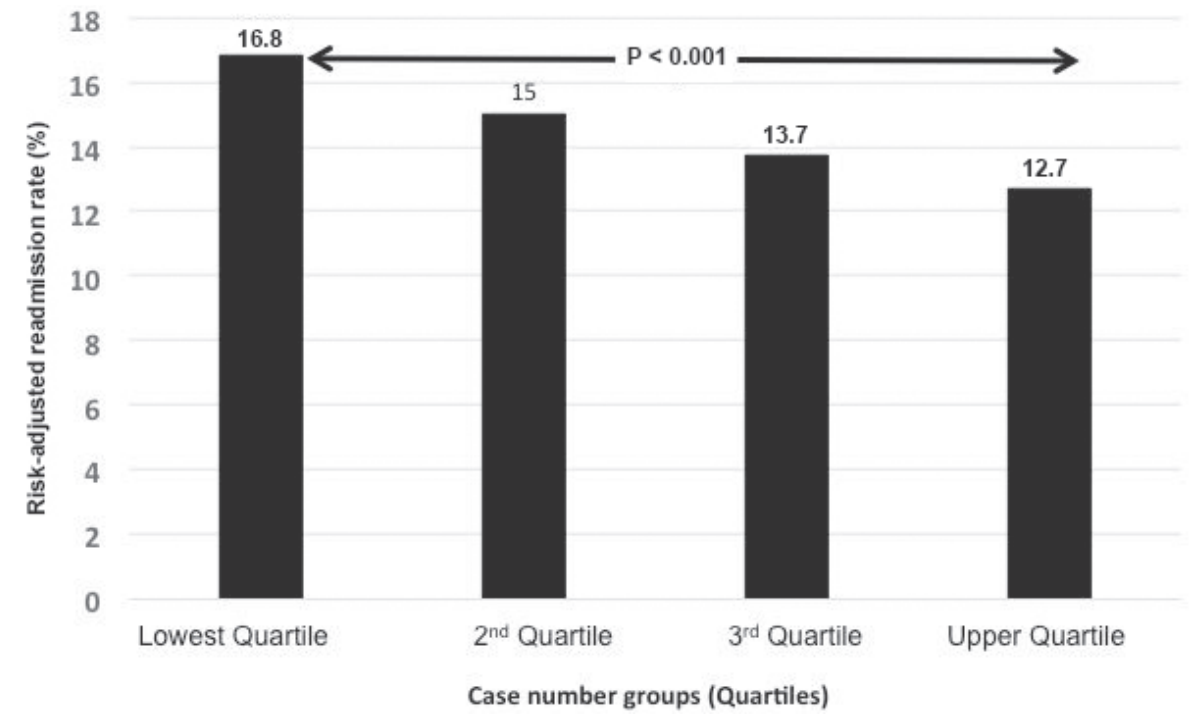

for the first time in 1979 and thus pointed out that case numbers and quality of results in medicine correlate. The surgical subjects or procedures are overrepresented here. The most comprehensive and validated data regarding their effects on patient care are available for visceral surgery (surgical oncology, colorectal, hepatobiliary and pancreatic as well as upper gastrointestinal surgery) and especially for oncological surgery.

\section{Surgical Oncology}

In the fundamental work of the group of John Birkmeyer, the relationship between quantity and quality was demonstrated both at the hospital level and at the surgeon level for a variety of complex surgical procedures $[4,5]$. The analysis was carried out on 2.5 million Medicare patients (1994-1999) with 14 surgical procedures (8 cancer operations, 6 cardiovascular procedures). They defined separation variables ( 5 cases with quintile formation) and mortality (hospital mortality or 30-day mortality) with risk adjustment using patient characteristics. The case-number effect was most pronounced within the complex esophageal and pancreatic resections (fig. 1).

The definition of low- and high-volume centers is extremely different in the American literature, with extremely low numbers of cases in the individual quintiles that are hardly transferable to German hospitals and departments [6].

In 47 systematic reviews, a clear statistical link between the riskadjusted 30-day mortality and the number of cases of the institution was shown [7]. For example, a 'high-volume' effect can be regarded as proven for many areas of highly specialized surgery [8]. It is less likely to reduce the occurrence of severe postoperative complications but rather the mortality through improved complication management, i.e. dealing with and mastering complications (see chapter on 'Failure to Rescue'). Also for Germany, such statistical connection was found for various complex interventions [9]. In 35 systematic reviews, including 32 with surgical indications, a volume-outcome relationship, 26 of which were related to the hospital and physician, was demonstrated [10]. The strongest correlation existed in high-risk interventions. In smaller procedures, which are associated with a low operational risk to begin with, the data situation is significantly poorer.

In all studies which investigated the correlation between the number of cases and the quality of the results so far, a curve-linear relationship was discovered. The higher the number of cases, the more likely good treatment results were achieved. The majority of studies investigated the correlation between case number and outcome quality with the endpoints 30-day mortality or hospital mortality. During 


\section{Surgical Skills}

Fig. 3. Correlation of procedure-specific skills of the surgeon and complication rate after bariatric surgery on the risk-adjusted complication rate (modified from [70]).

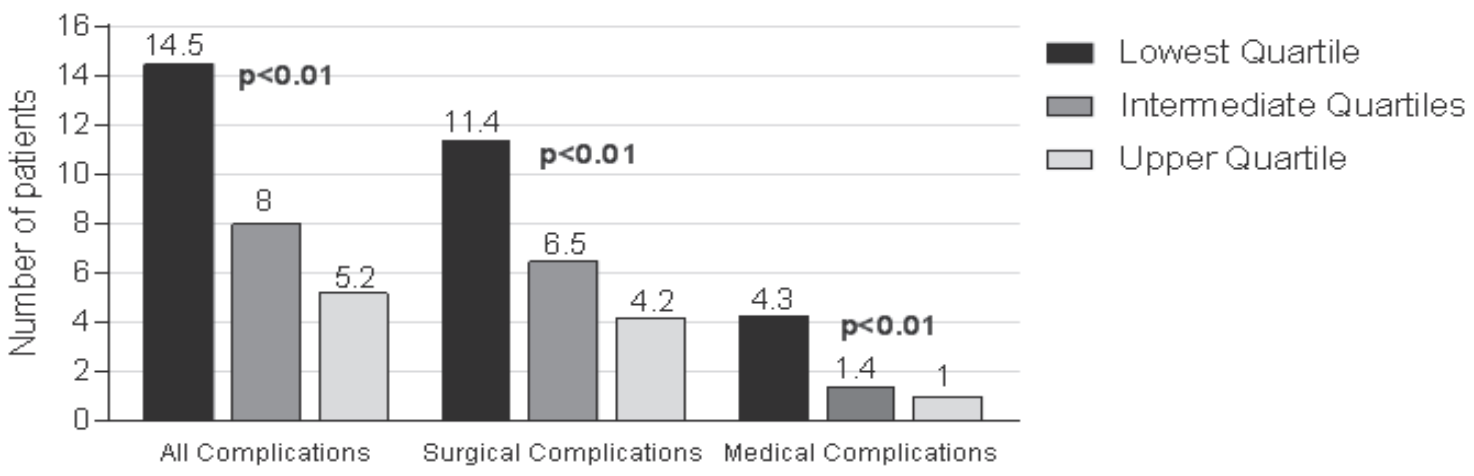

the past 15 years, this effect has also been confirmed for a variety of different surgical procedures (e.g. aortic aneurysm, breast cancer, gastrointestinal tumors, vascular interventions, and transplants) [4, $7,11,12]$. In addition to mortality, other surrogate parameters must be used for assessment, such as complication, reintervention and resuscitation rates and, last but not least, efficacy [13-16]. Thus, the case-dependent outcome quality, measured with hospital mortality, also correlates with the resuscitation rate after discharge within 30 days. Approximately 1 of 7 patients who are released from the hospital after major surgery will be readmitted within 30 days [15]. This rate is significantly lower in high-volume than in low-volume hospitals, which is important not only in the context of linked pay-forperformance models but also in high-risk cases, especially of elderly tumor patients, with high clinical relevance (fig. 2) [15, 17, 18].

The experience in Germany is not much different $[1,19]$. Through such analyses, reliable knowledge can also be acquired for health and distribution policy discussions. An example is the situation in pancreatic surgery. Evaluations of the DRG (diagnosis-related groups) data show that considerable published data from German hospitals are too optimistic. An overview of 58,000 patients aged 20 years or more had a hospital mortality of $10.1 \%$, while published studies of individual hospitals reported a mortality between 0 and $7.8 \%$. The complication rates and the ratio of reoperations (20.2\%) are also remarkable. In one quarter of German hospitals, only 1-2 pancreatic resections were performed each year. The adjusted mortality rate in hospitals with a case rate equal to or above the minimum levels for complex interventions of the esophagus and pancreas was significantly lower than in hospitals below the minimum. Similar results have been demonstrated in a recent study on pancreatic surgery with $10,000 \mathrm{AOK}$ (German common health insurance) patients who were operated in 683 hospitals. In the institutions which had performed only eleven such interventions in 3 years, mortality during the first year after surgery was $50 \%$ higher than in the quintile with the most operations (34.4 vs. 23.3\%) [20].

\section{Bariatric Surgery}

Because of its increasing importance, bariatric surgery is also regarded as a possible 'candidate' for Mm-R. The 'GEK Report
Krankenhaus 2016, which has just been published, has been devoted to this focus [21]. Since 2006 the interventions in obese patients (bariatric operations) have multiplied by a factor of eight [21]. Because of their concomitant and secondary illnesses, and also commonly restricted cardiopulmonary reserve, these patients are high-risk patients. Special attention is therefore paid to the quality of these interventions or to quantitative differences in the results of the different surgical procedures, particularly in the more effective, but also riskier methods such as gastric bypass and its variants with a correlation of procedure-specific skills of the surgeon and the complication rate (fig. 3) [22-24].

\section{Volume-Outcome Relationships in Other Procedures}

Systematic reviews show that there is data on the importance of minimum quantities for each type of surgery [8]. For most procedures, at least a moderate relationship between hospital performance and outcome quality can be found. Exemplary, below some more recent analyses can be found:

\section{Goiter Surgery}

The risk of permanent vocal cord paralysis after thyroid surgery decreases with the number of cases of the treating hospital [25]. The best results (study in 17,000 patients operated by about 5,000 surgeons) are achieved at an annual operating frequency of the surgeons of over 25 [26].

\section{Vascular Surgery}

Hospital mortality is an essential quality parameter for endovascular and open procedure of abdominal aortic aneurysm (AAA) [27]. Routine data can very well be utilized for the analysis of volume-outcome relationships. Of particular importance are correct patient selection and a multidisciplinary treatment approach. Under the aspect 'failure to rescue' (see above) a close relationship between 30-day mortality and hospital size was found for the open AAA procedure [28].

\section{Thoracic Surgery}

Based on data from the USA and the UK, a case-correlated lower complication rate was demonstrated for resections of lung 
cancer, with the infrastructure of the hospital and the availability of specialists being decisive [29].

\section{Transplantations}

A key factor in liver transplantation is the complication management and a standardized approach in interdisciplinary cooperation as offered by a high-volume center [30]. Training of the surgeon and his/her experience level have a unique influence on the early results after renal transplantations [31]. There is also a definite relationship between center volume and mortality in heart transplants [32]. Heart transplants in Germany are not under the influence of $\mathrm{Mm}-\mathrm{R}$ yet. It is therefore all the more remarkable that the Joint Federal Committee (Gemeinsamer Bundesausschuss (G-BA)), with reference to repeated abnormalities in regard to the mortality after heart transplantations at the University Hospital of Frankfurt/Main, has forbidden heart transplantations altogether, also referring to the low number of cases of lastly four per year [33].

\section{Minimum Volume Standards in Residency (Education in Surgery)}

\section{Operation Catalogs with Reference Numbers as Minimum Numbers}

Above all, surgery requires well-trained surgeons for high quality and safety standards. The impact of an $\mathrm{Mm}$ - $\mathrm{R}$ with a consecutive case concentration in appropriate centers is therefore to be considered not only with regard to comprehensive coverage but also with regard to the consequences for surgical training [34, 35]. The Guidelines for Residency Education Regulations ((Weiterbildungsordnung (WBO) ) contain guidelines for diagnostic and therapeutic techniques of the respective areas. They provide clear guidelines and transparency as to which quantity frameworks are the basis for the detailed requirements [36]. These numerical requirements are merely empirically defined reference numbers, the fulfillment of which is a minimum requirement. Surgical residents and attending surgeons are also accustomed to dealing with minimum numbers for which there is no evidence base. Nevertheless, an Mm-R with its effects on case rate concentrations and structural changes on residency programs is discussed intensively among medical professionals. In addition to a restriction of the possibilities of residency training (regional, temporal, content), there is a fear of a shifting and fragmentation of residency training with the classification of specialists of different competences and with a limited range of skills. Thus, it is argued over and over again that for reasons of residency training and an attractive offer for residents, complex procedures such as esophageal and pancreatic resections as well as gastrectomies or AAA cannot be discarded even if the annual number of cases is small. The typical argument being: 'If we are not allowed to operate on an elective AAA anymore, we will have problems with the emergency of a ruptured aneurysm.' This is barely acceptable from a patient's view. The consequence is also a loss of attractiveness of the hospital for patients and referring physicians $[37,38]$.
In order to realistically evaluate possible residency programs or the availability of complex operations for advanced training, the annual case numbers of maximum providers were evaluated in Munich and Augsburg [39]. According to the former residency program guidelines in Germany (WBO), the reference numbers for each surgical procedure, which were demanded by the surgical societies themselves, could not be implemented in the reality of daily clinical care. In recognition of the fact that highly specialized and complex visceral procedures could not be provided in all the necessary departments for the purpose of training, and that not all of the upcoming visceral surgeons had to know how to perform these procedures, more complex interventions were removed from the guidelines and a new supplementary training 'special visceral surgery' was created [36]. Even in this new specialized visceral surgery fellowship, however, the resections on the esophagus are no longer required. The discussion of this 'catalog clearance' is therefore important, since the argument that a service provided below the $\mathrm{Mm}-\mathrm{R}$ cannot be discarded as reasons for residency education are lacking formal evidence (see below).

\section{Surgery Is More than Operating}

If risk-adjusted complication rates are clearly correlated to individual experience and the intervention-specific skills of a surgeon, surgery and the surgeon should not be reduced to the work with the scalpel. An increasing specialization of the surgeon and the accompanying infrastructure needs to be taken into account; an interdisciplinary cooperation is essential. Objective criteria are taskallocated patient care with interdisciplinary coordinated concepts, shortening of the length of stay by means of structured processes that are primarily based on the quality of care and patient safety, and a stringent treatment management of preoperative performance planning up to the patient's discharge. Successful surgical treatment today is more than ever dependent on the basic conditions and, above all, on the extent to which we are in a position to adapt to the demands that lie outside our actual surgical core competence [35]. The future professional development and the changing hospital structures are closely linked. There is no doubt that in a subject such as surgery, there is also a demand for craftsmanship and manual skill with the particularly relevant 'practice makes the master' principle. Therefore, there must be sufficient time for exercise not only during residency training but also during later professional life in order to maintain quality. In order to achieve this, a certain critical amount is necessary. On the way to a competent surgeon, the definition of professional competences, which describe the profile of the knowledge and skills to be acquired at the end of the clinical development, should be conceived as a bridge between surgical training and subsequent clinical maturation towards a self-responsible surgical professional.

The necessary 'learning curve' for a relatively rare but technically demanding operation such as esophagectomy is therefore not to be completed within the framework of reference figures during residency or fellowship. A realistic number, supported by a study 
Fig. 4. Learning curves (decrease of the operating time in minutes depending on the experience level in years) for three operating procedures (modified from [41]).

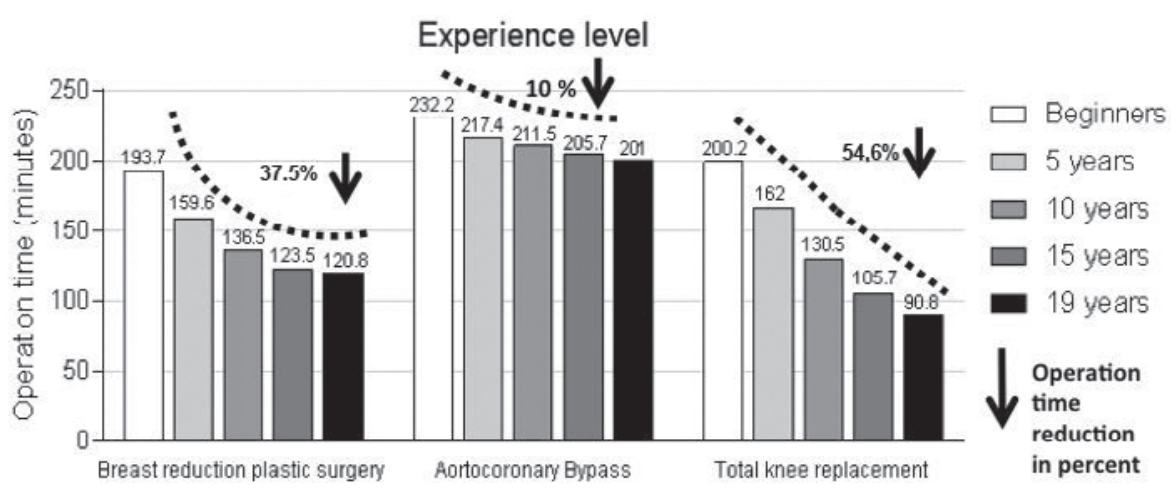

Experience level (years) with the aim of halving the mortality, is the requirement of 15 of such operations. A plateau of optimized long-term results in esophageal carcinoma was achieved only after 35-59 operations [40]: Between 1987 and 2010, 139 surgeons performed 1,821 esophagectomies. The success rate and endpoint of the study were the patients' mortality rates after 30 days as well as after 1, 2 and 5 years. The endpoint of the learning curve was reached when the mortality of the patients did not decrease with increasing number of operations. At 30-day mortality, which assessed the technical success of the operation, the surgeons reached the end of the learning curve after 15 operations. At this time, the mortality of the patients had decreased from 7.9 to $3.1 \%$. In the long-term results, which were also influenced by the detail of the operation and in particular the complete removal of the lymph nodes, the plateau was reached after 35-59 operations. Different learning curves for three further standard procedures are shown in figure 4 [41].

\section{Minimum Quantity Regulation in Accordance with $\S 136 b$ (1) Sentence 1 no. 2 SGB V}

In 2004, the Mm-R came into force. Because of this about a quarter of all acute care hospitals were affected nationwide. On the side of the medical professionals, there was an in-depth debate on the benefits and risks of establishing explicit minimum case numbers and the associated promotion of centralization and care by specialists $[6,37,38]$. The Joint Federal Committee (G-BA) established the procedures involved, including the required number of cases (per hospital and/or doctor) in a catalog [42]. Some minimum quantities have in the meantime been raised while others have been added to the catalog (table 1). With the regulation for the care of early and newborns and for stem cell transplants, there are only two Mm-R for non-surgical procedures.

In a principle judgment of the 3rd Senate of the federal social court of justice (Bundessozialgericht (BSG)) from September 12th, 2012 on the setting of minimum amounts for total knee replacement, the essential elements of the legal framework of the G-BA were confirmed [43]. The complaint lodged by a hospital against this $\mathrm{Mm}-\mathrm{R}$ of the G-BA was declined by the lower court (Landessozialgericht (LSG)) Berlin-Brandenburg (AZ: B 3 KR
Table 1. Currently valid minimum quantity catalog [42]

\begin{tabular}{ll}
\hline Procedure/Intervention & $\begin{array}{l}\text { Minimum amount } \\
\text { per hospital per year }\end{array}$ \\
\hline Liver transplantation & 20 \\
Kidney transplantation & 25 \\
Complex procedures on esophagus & 10 \\
Complex procedures on pancreas & 10 \\
Stem cell transplantation & 25 \\
Total knee replacement & 50 \\
Coronary procedures & \\
Care for premature and newborn babies & b \\
\hline
\end{tabular}

anclusion of procedure into catalog is without the determination for a minimum amount for now.

${ }^{\text {bW }}$ as 30 before the judgment of January 19, 2012.

10/12 R). In particular, it was to be clarified by the LSG whether the determination of the minimum amounts to 50 interventions per year was legal. According to the G-BA, minimum levels are an integral part of quality assurance and targeted management of hospital treatment - and will continue to do so. This clarifies that the definition of minimum amounts with a defined threshold is a normative process which is based on these two criteria [43]. The quality of the treatment outcome of elective services is already dependent to a certain extent on the quantity of the services provided, if there is sufficient scientific evidence that links case amount to quality [44].

\section{'Failure to Rescue': The Handling of Complications Is Important}

There is a significant correlation between number of cases and morbidity in operative procedures on the upper and lower gastrointestinal tract. However, this does not correlate with mortality in a linear fashion (fig. 5). The term 'failure to rescue' attempts to take into account that it is not the occurrence of complications per se but rather the handling of these that is important. It also describes the disease-specific mortality after operative interventions as an important hospital quality parameter [45-48]. 
Fig. 5. 'Failure to rescue'* correlates with mortality and clinic case number, while the frequency of severe complications in case groups is hardly different (modified from severe complications that have been discovered/treated too late/ inadequately). [46]) ${ }^{*}$ death after

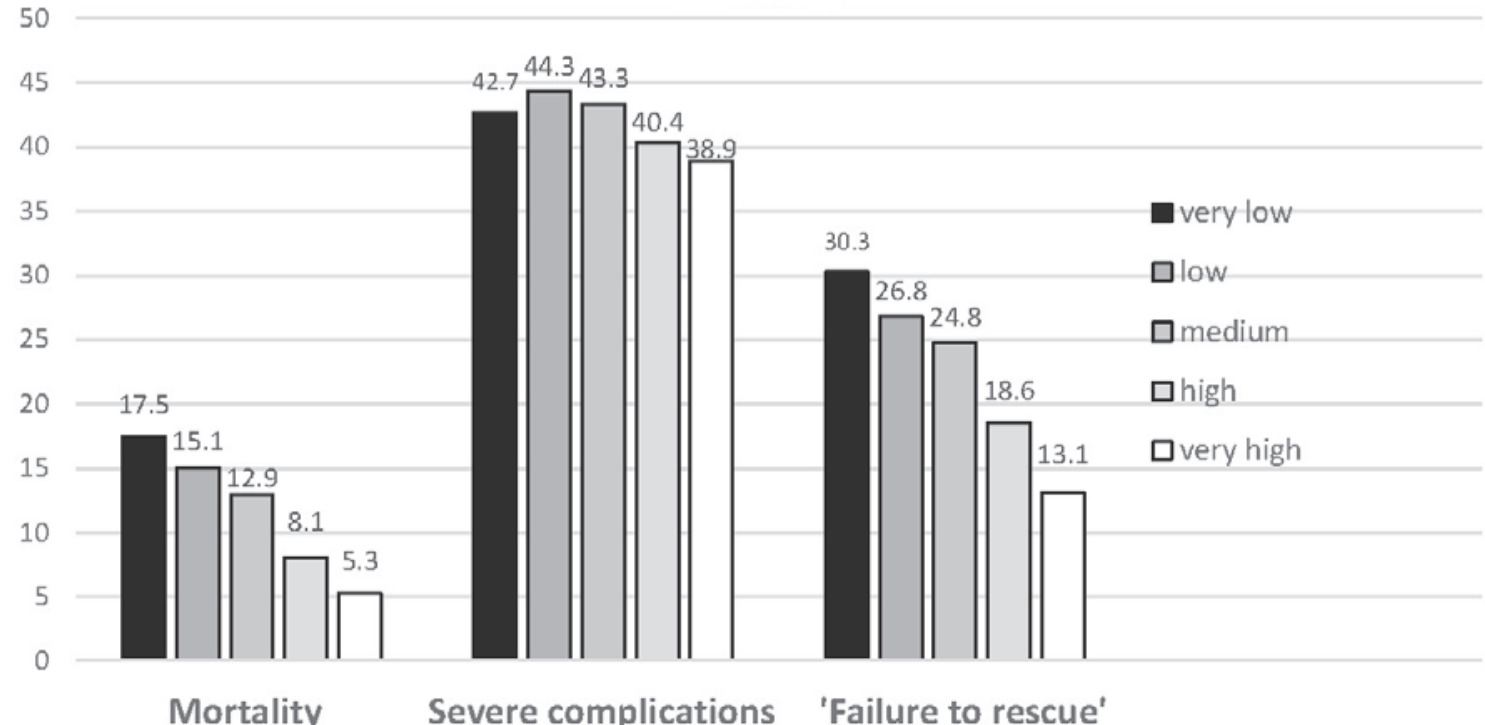

The use of trained personnel and specialization in intensive care units are also crucial [49]. When using inadequately trained staff in intensive care units, the rate of reintubations (2.4-fold), acute renal failure (7-fold), lethality (3.5-fold), and treatment costs (1.6-fold) increase substantially [13]. A large multinational study shows the importance of adequate and, above all, early-stage induced intensive care [50]. In Europe, significantly more people die after an operation than previously thought. Almost three quarters of patients who died postoperatively were never transferred to an intensive care unit. Often the hospital does not recognize which patients particularly need intensive care after the operation. The introduction of 'rapid response teams' is associated with fewer cardiopulmonary failure, unscheduled readmission to the intensive care unit, and mortality of patients in hospitals [51]. Early detection of deterioration of the patient's health and subsequent preventive measures are key to survival.

Almost $90 \%$ of all deaths refer to those $20 \%$ of patients who have the highest risk [48]. Quality of care is also reflected in how quickly a patient regains the ability to live independently. Patients who have been operated in a colorectal high-volume center recover more quickly and have double the chance of being released directly to home rather than into a care facility compared to a low-volume hospital [52]. Complications after a cancer operation also affect long-term survival. There is a link between complications and reduced long-term survival [53]. Anastomotic insufficiency, excessive blood loss, and (abdominal) sepsis were associated with reduced 5-year survival. An increase in the number of complications had no additive effect. Cost-carrier calculations also show that, for example, pancreatic resections can only be performed cost-neutrally in centers with a low complication rate. In the case of complications, not only the length of stay but also the average overall costs increases significantly [54].

The organizational structure of the hospital (teams, tumor board, and emergency care) with a high-performance intensive care unit, emergency diagnostic tools, and the possibility of inter-
Table 2. Minimum amount suggestions by hospital groups in the USA: Dartmouth-Hitchcock Medical Center, Johns Hopkins Medicine, University of Michigan [5]

\begin{tabular}{llc}
\hline Procedure & $\begin{array}{l}\text { Hospital, minimum } \\
\text { amount per year }\end{array}$ & $\begin{array}{l}\text { Surgeon, minimum } \\
\text { amount per year }\end{array}$ \\
\hline Bariatric surgery (stapler) & 40 & 20 \\
Esophageal cancer & 20 & 5 \\
Lung cancer & 40 & 20 \\
Pancreatic cancer & 20 & 5 \\
Rectum & 15 & 6 \\
Carotis stenting & 10 & 5 \\
Complex procedure on AAA & 20 & 8 \\
Mitral valve replacement & 20 & 10 \\
Hip replacement & 50 & 25 \\
Total knee replacement & 50 & 25 \\
\hline
\end{tabular}

$\mathrm{AAA}=$ Abdominal aortic aneurysm.

ventional measures is more important than the single hospital experience. These requirements are expected to contribute significantly to the improvement of the treatment of intestinal carcinomas to the best possible quality level, thereby leading to a further prognosis improvement [55-57].

\section{Specialization and Center Formation}

Particularly in the case of visceral surgery, specialization and center formation are an important prognostic factor in addition to the individual surgeon [58]. Reports from the countries in which the centralization has been carried out in the case of complex operations support this fact [59]. Between 2004 and 2009, the proportion of hospitals that performed more than 10 pancreatic cancer surgeries per year in the Netherlands increased from 50 to $90 \%$, and the death rate after the surgery halved in the same period 
Table 3. Comparison of the Clinical Cancer Registry (CCR) data with the benchmark data of the colorectal cancer centers (CCC); reported differences for four qualitatively significant parameters required in the $\mathrm{S} 3$ guideline; report year 2009 [67]

\begin{tabular}{|c|c|c|c|c|}
\hline \multirow[t]{2}{*}{ Quality parameters (S3 guideline) } & \multicolumn{2}{|l|}{ CCCR } & \multicolumn{2}{|l|}{ CCC } \\
\hline & $\mathrm{n}$ & $\%$ & $\mathrm{n}$ & $\%$ \\
\hline $\mathrm{R} 0$ resections colon cancer & 9,395 & 85.4 & 9,842 & 95.6 \\
\hline $\mathrm{R} 0$ resections rectal cancer & 4,310 & 80.7 & 5,603 & 94.8 \\
\hline Patients with $>12$ examined lymph nodes & 12,863 & 91.6 & 12,128 & 94.5 \\
\hline Chemotherapy in stage III colon cancer & 2,315 & 61.0 & 2,244 & 73.8 \\
\hline
\end{tabular}

(from 8 to 4\%). A centralization of esophageal surgery with a minimum of 20 resections/center/year reduced the morbidity and mortality in esophageal cancer by a quarter and also practically halved in the case of gastric cancer since 2011. Highly specialized departments (such as centers for the upper gastrointestinal tract) were centralized in a process developed by the Dutch Surgical Society together with the cost-carriers and the Ministry Quality Program (Dutch Upper GI Cancer Audit (DUCA)) with mandatory participation in a registry. Similar favorable experiences exist within colorectal cancer surgery since 2009, having been created under the leading participation of the surgical professional society, none the least because of the enforcement of interdisciplinary multimodal therapy concepts that are relevant for long-term prognosis $[56,60]$.

Comparable results come from the USA. In more than 3 million patients it was shown that colorectal operations have become safer through centralization. The 'Leapfrog Group', a large hospital carrier, is a vehement advocate of minimum amounts and dictates these to its members [61]. Based on this Mm- $\mathrm{R}$ an impressive reduction of deaths was reached. Other hospital groups in the USA have also made similar suggestions (table 2).

In Sweden, a number of rectal cancer registries, which had been recording lots of data over the years, showed that centralization is an independent prognostic factor [62]. The recurrence of the tumor in the small pelvis was reduced from 8 to $3.5 \%$ and the survival of the patients increased from 38 to $61 \%$ after 5 years. This went hand in hand with further improvements of important parameters in the treatment of cancer. There are different results on the extent to which these developments are caused by the centralization, i.e. by a higher rate of adjuvant chemotherapies [63-65]. Liver resections for the curative treatment of metastatic colorectal cancer are performed three times as frequently in tertiary hospitals [66]. If one considers qualitatively significant parameters required in the S3 guideline for intestinal cancer surgery, a favorable effect of center formation is shown by comparison of the benchmark data of the gastrointestinal centers certified by the German Cancer Association with those of the General Clinical Cancer Registry (table 3) [67].

A volume-outcome relationship is defined not only by the number of cases in a hospital or department but also by the degree of specialization and the caseload of the individual surgeon [68]. Most studies consider a volume-outcome relationship of the hospital and the doctor $[8,10]$. The factor physician is to be weighted differently in comparison to the importance of the clinical case quantity for the individual types of interventions [69-72]. The best results are obtained, as expected, from high-volume surgeons in a high-volume hospital (table 4) [11].
Table 4. Gastrectomy: number of surgeons, patients, und mortality rate sorted by volume categories for hospitals and surgeons [11]

\begin{tabular}{lccc}
\hline Volume category & Surgeon, $\mathrm{n}$ & Patients, $\mathrm{n}$ & Mortality, \% \\
\hline 1. Low hospital/low surgeon & 895 & 2,336 & 12.2 \\
2. Low hospital/high surgeon & 81 & 936 & 9.5 \\
3. High hospital/low surgeon & 320 & 876 & 8.0 \\
4. High hospital/high surgeon & 91 & 2,281 & 4.3 \\
\hline All $^{a}$ & 1,387 & 6,429 & 8.4 \\
\hline
\end{tabular}

aff all patients were to be operated in category 4, there would be 264 less deaths (276 vs. 540$)$.

In an effort to measure the quality of surgical work quantitatively, the so-called 'intervention-specific volume' (procedure-specific volume) was defined [72]. It is calculated as the quotient of the number of defined interventions performed by a surgeon and the number of all operations. In this regard, the 30-day mortality of nearly 700,000 patients from 2008 to 2013, which had been operated by a total of 25,000 surgeons, was investigated. The surgeons performed one of eight interventions: carotid endarterectomy, coronary artery bypass, heart valve replacement, AAA surgery, pneumonectomy, cystectomy, pancreatectomy, or esophagectomy. The average specialization within the meaning of procedure-specific volumes ranged from $6 \%$ in esophagectomy to $40 \%$ in bypass surgery. Within the individual procedures, the degree of specialization with regard to the least and the most specialized surgeons varied between 0.1 and $43 \%$. Risk reduction due to higher specialization fluctuated between 15\% (bypass surgery) and $46 \%$ (valve replacements). In five surgeries (carotid endarterectomy, valve replacement, pneumonectomy, cystectomy, and esophagectomy) the risk of death was reduced more by specializing than by the operation volume. This was shown for the surgeon for the respective procedure and, in itself, the more operations had been performed, the better the outcome resulted. Risk factors of the patients were taken into account in the calculations.

\section{Certification Criteria of Surgical Societies}

Switzerland has defined highly specialized medicine by analysis of statewide numbers and made specifications that include detailed requirements for the structural and process quality, which to a significant extent also include minimum amounts [73]. In the field of intensive care, the criteria of the society (Swiss Society for Intensive Care Medicine (SGI)) are used to evaluate the structural quality. 
Fig. 6. Surgery on the esophagus, stomach and pancreas. The minimum number of cases required for the certification of operations per year in relation to the individual center types (modified from [74]).

\begin{tabular}{|c|c|c|c|}
\hline Intervention & $\begin{array}{l}\text { Competence } \\
\text { center }\end{array}$ & $\begin{array}{l}\text { Reference } \\
\text { center }\end{array}$ & $\begin{array}{l}\text { Center of } \\
\text { excellence }\end{array}$ \\
\hline $\begin{array}{l}\text { a. Esophageal cancer resections } \\
\text { OPS:5-426, 5-438 }\end{array}$ & 15 & 25 & $>35$ \\
\hline $\begin{array}{l}\text { b. Other esophageal procedures } \\
\text { OPS:5-425, 5-422 }\end{array}$ & 5 & 10 & 10 \\
\hline $\begin{array}{l}\text { c. Stomach resections or gastrectomy for cancer } \\
\text { OPS:5-436, } 5-441,5-437,5-443.3,5-424.2\end{array}$ & 15 & 25 & $>35$ \\
\hline $\begin{array}{l}\text { d. Other gastric procedures } \\
\text { OPS:5-343, 5-435,5-448, 5-449 }\end{array}$ & 5 & 10 & 10 \\
\hline Sums of $a$. and $c$. & $>35$ & $>50$ & $>100$ \\
\hline $\begin{array}{l}\text { a. Pancreatic head resections and total pancreatectomies } \\
\text { OPS:5-524.1, 5-524.2, 5-524.3, 5-525.0, 5-525.1, 5-525.2 }\end{array}$ & 25 & 50 & 75 \\
\hline $\begin{array}{l}\text { b. Distal-and segmental pancreatectomies } \\
\text { OPS: } 5-524.0,5-524.4\end{array}$ & 5 & 10 & 15 \\
\hline $\begin{array}{l}\text { c. Other pancreatic resections for the treatment of acute pancreatitis or inoperable } \\
\text { malignant tumors and enucleation of benign tumors } \\
\text { OPS:5-520, 5-521, 5-522, 5-523, 5-527, 5-529.0-m, 5-529.-no, 5-512, 5-518 }\end{array}$ & 10 & 20 & 30 \\
\hline $\begin{array}{l}\text { d. Interventional therapy (PTCD, abscess drain, Stenting) } \\
\text { OPS: 1-553, 3-13c, 5-514.6Stelle3, 5-517, 5-526, 5-529.n2-x, 5-529.p0-x, 8-146.2, 8-148.1, 8-154.3 }\end{array}$ & 60 & 80 & 120 \\
\hline
\end{tabular}

Fig. 7. Obesity and metabolic surgery. Criteria for center certification. Minimum intervention numbers, which must be documented in two reference years (modified from [74]).

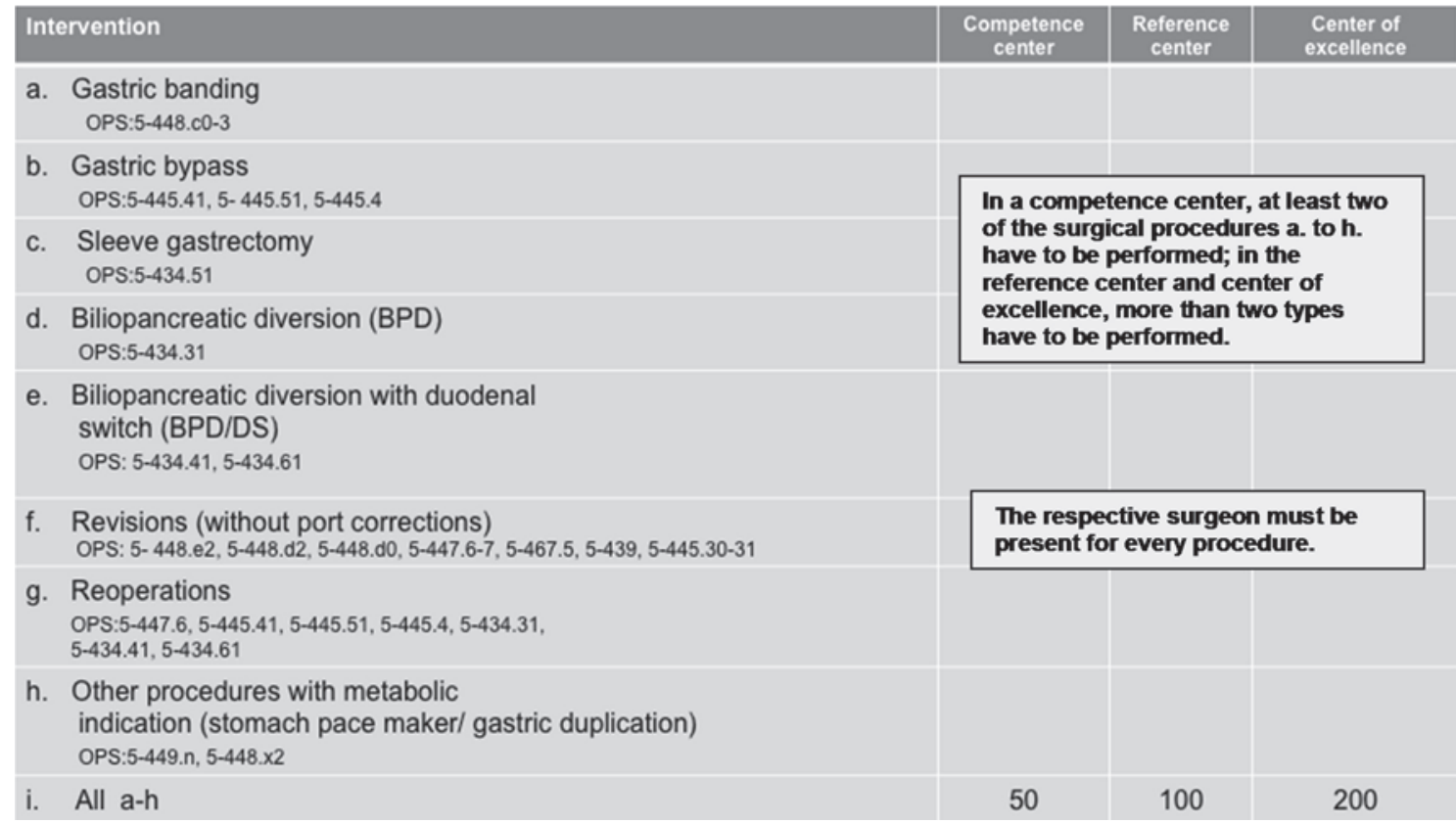

Overall, the concept of the list of criteria is very similar to the certification process of the German Society of General and Visceral Surgery (DGAV) [74]. In a graded certification scheme, the DGAV has outlined both structural requirements and Mm-R [74]. The determination of competence levels is carried out in three stages, depending on the personnel and material equipment, the clinical experience, the training capacity, and scientific activity: competence center, reference center, and center of excellence.

Competence center is defined as a department whose personnel and factual equipment and experience ensure a good quality and, if available, a guideline-appropriate treatment. In addition to the conditions applicable to a competence center, a reference center has resident training and scientific work opportunities. A center of excellence is one of the leading and largest facilities in clinical experience, personnel, and factual equipment as well as scientific work in the respective field (fig. 6, 7) [74].

From the German Surgical Society's point of view, it is particularly exciting that the quality assurance programs as well as the center certification process, currently new in the field of bariatric surgery, are recognized by the public and especially by the costcarriers [21]. In Germany, many patients are still referred to suboptimal hospitals; there is a big gap between the conscientious requirements and the reality of care. A stronger specialization does not necessarily lead to a demise of hospitals. Through cooperation of hospitals, it is possible to provide more efficient services. Basic and emergency care are also not affected if the specialization is re- 
stricted to elective interventions. For the latter, many patients are willing to accept farther travelling distances. However, there is still a considerable need for action with regard to a performance concentration in the respective equipped hospitals. The minimum amounts laid out so far must be observed and controlled, and the regulations should be extended to other indications [2].

\section{Conclusion}

A minimum amount of cases helps to ensure and increase patient safety and treatment quality. However, an exact threshold value with separation accuracy for poor quality (below) and good quality (above) cannot be established based on scientific evidence. This definition remains a normative act which cannot only be based on surrogate parameters such as reference values from the external quality assurance programs but it must also be in line with a supply control (fig. 8).

In a systematic literature evaluation of the volume-outcome relationship, a supposed contrast between minimum amounts and evidence was discussed extensively, with the conclusion that the results of the analyses were ambiguous [8]. The setting of minimum quantities could lead to the exclusion of hospitals which ensure good quality of care. However, the alternative of setting no minimum quantity has the disadvantage that patients are treated with poor quality in some hospitals. It has already been emphasized several times that this is not just the outcome of the hospital's procedure but that structural and procedural conditions have a pivotal role.

In response to the question posed in the title, i.e. 'Minimum quantities in surgery - are we there yet?', the surgical societies have already taken on the subject of the required number of cases with the development of suitable center and certification structures, but what is lacking in the sense of effective supply management is the introduction of a regulatory framework for the structuring of such centers and their certification [74-76]. Binding requirements, such as those developed by the DUCA or the Dutch Surgical Colorectal Audit, have to be created by the surgical societies, health insurances, and federal institutions $[53,56,60]$. The Institute for Quality Assurance and Transparency in Healthcare (Institut für Qualitätssicherung und Transparenz im Gesundheitswesen (IQTiG)) is bound to establish these criteria.

It is a daily confirmed surgical experience that good results of complex interventions in addition to correct indication and procedure selection do not only require excellent manual surgical skills (availability of specialists as an expression of structural quality) but also, above all, a high process quality. This can only be ensured by constantly training all relevant specialists and professional groups in relevant centers [71, 77]. Thus, as an appeal to one's own profession, there is a further need for action, which is self-restraint in selfresponsibility but also the implementation of regulatory requirements [5]. $40 \%$ of surgeons in the USA have abandoned 'high-risk procedures' on their own; the mortality decreased from 9.8 to $3.2 \%$. For AAA with 18,500 cases/year, 464 lives could be saved by limit-

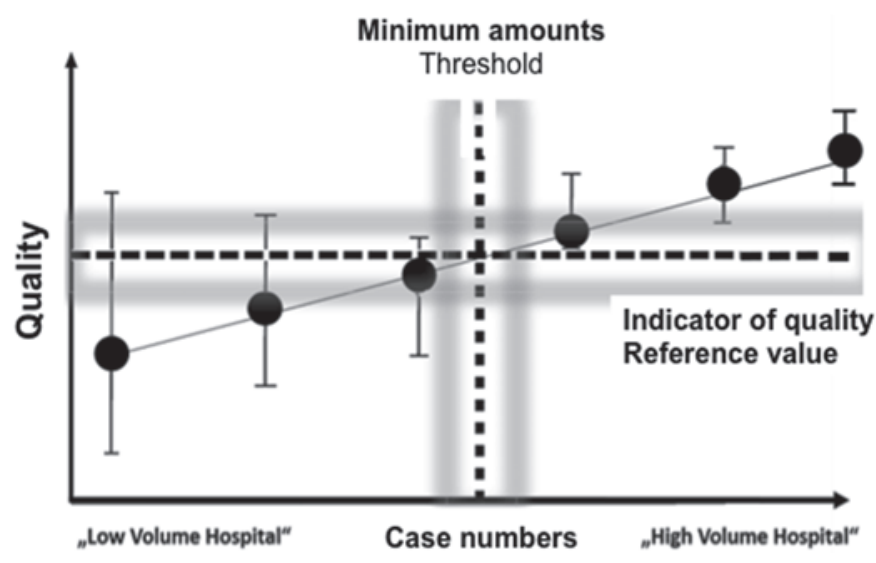

Fig. 8. Schematic representation of a linear relationship between number of cases and quality. The determination of a threshold value is made e.g. oriented to a reference value of selected quality indicators (surrogate parameters).

ing these procedures to hospitals with at least 30 cases/year [78]. Last but not least, there is also the insight that 'high-risk procedures' cannot be stated in the form of indicative figures in the residency education catalogs, and that the training argument as well as the lack of competition are not acceptable as an argument for a performance below the recommended minimum case amounts [79]. It is also necessary to have an open and transparent approach to the affected care providers. In Switzerland, for example, hospitals or departments excluded from the provision of highly specialized surgery are being published including the relevant reasons [73].

From extensive research with the available data and evaluation of a surgical clinician, a personal assessment should be allowed: No surgeon would select a low- or even ultra-low-volume hospital for him-/herself or his/her relatives. If, on the basis of personal responsibility for our patients, clever self-assessment and self-restraint would dominate rather than endless discussions about an unexplained evidence base of minimum amounts and thresholds, such a paper would not have to be written, because it ultimately is a matter of common sense.

That it must be written nevertheless indicates that self-understanding is not self-evident. When it comes to appreciation and recognition of the health care system, it is necessary to improve different interfaces and structures in order to take these values adequately into account [80]. This ranges from individual personal attitudes to general regulatory frameworks and structures. The importance of specialization and division of labor in surgery has already been described by the philosopher Immanuel Kant: 'All crafts and arts have gained by division of labor, in which not one does everything, but each one is confined to certain works in order to do so more perfect and to do it with greater ease. Where the works are not so distinguished and distributed, where everyone is a jack of all trades, the trades are still in the greatest barbarism' [81].

\section{Disclosure Statement}

No potential conflicts of interest were disclosed by the authors. 


\section{References}

1 Nimptsch U, Peschke D, Mansky T: Mindestmengen und Krankenhaussterblichkeit - Beobachtungsstudie mit deutschlandweiten Krankenhausabrechnungsdaten von 2006 bis 2013. Gesundheitswesen 2016;DOI: 10.1055/s-0042-100731.

2 Loos S, Albrecht M, Schiffhorst G, Ochmann R, Möllenkamp N: Faktencheck Krankenhausstruktur. Spezialisierung und Zentrenbildung. Gütersloh, IGES|Bertelsmann Stiftung, 2016. https://www.bertelsmann-stiftung.de/fileadmin/files/Projekte/Faktencheck_Gesundheit/FC_Krankenhausstruktur_Studie_final.pdf.

3 Luft HS, Bunker JP, Enthoven AC: Should operations be regionalized? The empirical relation between surgical volume and mortality. N Engl J Med 1979;301:13641369.

4 Birkmeyer JD, Siewers AE, Finlayson EVA, Stukel TA, Lucas FE, Batista I, Welch HG, Wennberg DE: Hospital volume and sugical mortality in the United States. N Engl J 2002;346:1128-1137.

5 Urbach DR: Pledging to eliminate low-volume surgery. N Engl J Med 2015;373:1388-1390.

6 Geraedts M: Spärliche Evidenz für explizite Mindestmengen. Dtsch Ärztebl 2004;101:1402-1404.

7 Amato L, Colais P, Davoli M, Ferroni E, Fusco D, Minocci S, Moirano F, Sciatella P, Vecchi S, Ventura M Perucci CA: Volume and health outcomes: evidence from systematic reviews and from evaluation of Italian hospital data (Article in Italian). Epidemiol Prev 2013; 37(suppl 2):1-100

8 Pieper D, Mathes T, Neugebauer EAM, Eikermann M: State of evidence on the relationship between highvolume hospitals and outcomes in surgery: a systematic review of systematic reviews. J Am Coll Surg 2013; 216:1015-1025.

9 Hentschker C, Mennicken R, Reifferscheid A, Thomas D, Wasem J, Wübker A: Der kausale Zusammenhang zwischen Zahl der Fälle und Behandlungsqualität in der Krankenhausversorgung. Essen, RWI Materialien 101, 2016. http://www.rwi-essen.de/media/content/pages publikationen/rwi-materialien/rwi-materialien_101. pdf.

10 Pietsch B, Matthias K, Gruber S: Evidenz von VolumeOutcome-Beziehungen und Mindestmengen: Diskussion in der aktuellen Literatur. 5. QS-Konferenz des Gemeinsamen Bundesausschusses. 14. Oktober 2013, Berlin. https://www.g-ba.de/downloads/17-98-3578/ 2013-10-14_PV5_1_Pietsch.pdf.

11 Halm EA, Lee C, Chassin MR: Is volume related to outcome in health care? A systematic review and methodologic critique of the literature. Ann Intern Med 2002;137:511-520.

12 Gruen RL, Pitt V, Green S, Parkhill A, Campbell D, Jolley D: The effect of provider case volume on cancer mortality: systematic review and meta-analysis. CA Cancer J Clin 2009;59:192-211

13 Dimick JB, Pronovost PJ, Heitmiller RF, Lipsett PA Intensive care unit physician staffing is associated with decreased length of stay, hospital cost, and complications after esophageal resection. Crit Care Med 2001; 29:753-758.

14 Glance LG, Kellermann AL, Osler TM, Li Y, Mukame DB, Lustik SJ, Eaton MP, Dick AW: Hospital readmission after noncardiac surgery. The role of major complications. JAMA Surg 2014;149:439-445.

15 Tsai TT, Joynt KE, Orav JE, Gawande AA, Jha AK: Variation in surgical-readmission rates and quality of hospital care. N Engl J Med 2013;369:1134-1142.

16 Short MN, Ho V, Aloia T: Impact of processes of care aimed at complication reduction on the cost of complex cancer surgery. J Surg Oncol 2015;112:610-615.
17 Girotti ME, Shih T, Dimick JB: Health policy update. Rethinking hospital readmission as a surgical quality measure. JAMA Surg 2014;149:757-758.

18 Nathan H, Atoria CL, Bach PB, Elkin EB: Hospital volume, complications, and cost of cancer surgery in the elderly. J Clin Oncol 2015;33:107-114.

19 Peschke D, Nimptsch U, Mansky T: Umsetzung der Mindestmengenvorgaben: Analyse der DRG-Daten. Eine retrospektive Studie der Jahre 2005-2011. Dtsch Arztebl Int 2014;111:556-563.

20 Alsfasser G, Leicht H, Günster C, Rau BM, Schillinger G, Klar E: Volume-outcome relationship in pancreatic surgery. Br J Surg 2016;103:136-143.

21 Augurzky B, Wübker A, Pilny A, Fels K, Bohm S, Priess H-W, Reinacher U, Lehmann B: Adipositaschirurgie. BARMER GEK REPORT KRANKENHAUS 2016. Schriftenreihe zur Gesundheitsanalyse Band 40. Siegburg, Asgard, 2016, pp 90-157.

22 Nguyen NT, Paya M, Stevens CM, Mavandadi S, Zainabadi K, Wilson SE: The relationship between hospital volume and outcome in bariatric surgery at academic medical centers. Ann Surg 2004;240:586-593; discussion 593-594.

23 Birkmeyer NJ, Dimick JB, Share D, Hawasli A, English WJ, Genaw J, Finks JF, Carlin AM, Birkmeyer JD; Michigan Bariatric Surgery Collaborative: Hospital complication rates with bariatric surgery in Michigan. JAMA 2010;304:435-442.

24 Zevin B, Aggarwal R, Grantcharov TP: Volume-outcome association in bariatric surgery: a systematic review. Ann Surg 2012;256:60-67.

25 Maneck M, Dotzenrath C, Dralle H, Fahlenbrach C, Paschke R, Steinmüller T, Tusch E, Jechke E, Günster $\mathrm{C}$ : Komplikationen nach Schilddrüsenoperationen in Deutschland. Eine Routinedatenanalyse von 66.902 AOK-Patienten. Chirurg 2017;88:50-57.

26 Adam MA, Thomas S, Youngwirth L, Hyslop T, Reed S, Scheri RP, Roman SA, Sosa JA: Is there a minimum number of thyroidectomies a surgeon should perform to optimize patient outcomes? Ann Surg 2017;265:402407.

27 Debus RS, Torsello C, Behrendt Petersen J, Grund mann RT: Perioperative Letalität bei der Versorgung abdomineller Aortenaneurysmen in Deutschland. Ein Vergleich von Routinedaten der DAK-Gesundheit mit Registerdaten der DGG. Chirurg 2015;86:1005-1011.

28 Hicks CW, Wick EC, Canner JK, Black JH 3rd, Arhuidese I, Qazi U, Obeid T, Freischlag JA, Malas: Hospital-level factors associated with mortality after endovascular and open abdominal aortic aneurysm repair. JAMA Surg 2015;150:632-636.

29 Al-Sahaf M, Lim E: The association between surgical volume, survival and quality of care. J Thorac Dis 2015;7(suppl 2):152-155

30 Houben P, Gotthardt DN, Radeleff B, Sauer P, Büchler MW, Schemmer P: Komplikationsmanagement nach Lebertransplantation. Erhöhung der Patientensicherheit durch standardisiertes Vorgehen und interdisziplinäre Kooperation. Chirurg 2015;86:139-145.

31 Thomas M, Rentsch M, Drefs M, Andrassy J, Meiser B, Stangl M, Jauch KW, Guba M: Impact of surgical training and surgeon's experience on early outcome in kidney transplantation. Langenbecks Arch Surg 2013; 398:581-585

32 Pettit SJ, Jhund PS, Hawkins NM, Gardner RS, HajYahia S, McMurray JJV, Petrie MC: How small is too small? A systematic review of center volume and outcome after cardiac transplantation. Circ Cardiovasc Qual Outcomes 2012;5:783-790
33 G-BA: Ergebnis des Strukturierten Dialogs: Künftig keine weiteren Herztransplantationen im Universitätsklinikum Frankfurt am Main. GBA Pressemittelung. Berlin 4.8.2016. https://www.g-ba.de/institution/presse/ pressemitteilungen/634/.

34 Bauer H: Chirurgie in neuen Strukturen. Auswirkungen auf den Nachwuchs. Trauma Berufskrankh 2007; 9(suppl 3):264-273.

35 Bauer H: Chirurgie ist mehr als Operieren; in Schwenk W, Freys SM, Kalff JC (Hrsg): Perioperative Medizin. Stuttgart, Thieme, 2017, pp 548--554.

36 BÄK: (Muster-)Richtlinien über den Inhalt der Weiterbildung (MWBO 2003) in der Fassung vom 18.02.2011. http://www.bundesaerztekammer.de/fileadmin/user upload/downloads/RiliMWBO20110218.pdf.

37 Deutscher Ärztetag Bremen 2004: TOP II: Durch Quantität zu Qualität? - Folgen der Konzentration und Zentralisierung von medizinischer Versorgung für die Bevölkerung. http://www.bundesaerztekammer.de/ arzt2004/.

38 Flintrop J, Rabbata S: TOP II: Mindestmengen in der Medizin - Qualität kommt nicht vom Fließband. Dtsch Ärztebl 2004;101:A-1546/B-1282/C-1234.

39 Geißler B, Mayer H, Witte J: Bedeutung der Mindestmengen für die Weiterbildung zum Facharzt/Fachärztin für Viszeralchirurgie. Der Chirurg BDC 2003 9:M281-282.

40 Markar SR, Mackenzie H, Lagergren P, Hanna GB, Lagergren J: Surgical proficiency gain and survival after esophagectomy for cancer. J Clin Oncol 2016;34:15281536

41 Maruthappu M, Duclos A, Lipsitz RS, Orgill D, Carty MJ: Surgical learning curves and operative efficiency: a cross-specialty observational study. BMJ Open 2015; 5:e006679.

42 G-BA: Mindestmengenregelungen, Mm-R, Stand: 17 März 2016, des Gemeinsamen Bundesausschusses gemäß $₫ 136 \mathrm{~b}$ Absatz 1 Satz 1 Nummer 2 SGB V für nach \$ 108 SGB V zugelassene Krankenhäuser; zuletzt geändert am 17. März 2016. https://www.g-ba.de/ downloads/62-492-1156/Mm-R_2016-03-17_iK-201601-01-2016-04-07.pdf.

43 G-BA: Qualitätssicherung BSG: Festsetzung von Mindestmengen bei Knie-TEP grundsätzlich möglich rechtliche Überprüfung wird fortgesetzt. https:// www.g-ba.de/downloads/34-215-453/22-2012-09-13BSG-MM-Knie.pdf.

44 Trefz U: Mindestmengen aus medizinrechtlicher Sicht - eine Darstellung zum Bereich der stationären Krankenhausversorgung unter Berücksichtigung der neueren Rechtsprechung. 2013. https://www.g-ba.de/downloads/17-98-3580/2013-10-14_PV5_3_Trefz.pdf.

45 Buettner S, Gani F, Amini, Spolverato G, Kim Y, Kilic A, Wagner D, Pawlik TM: The relative effect of hospital and surgeon volume on failure to rescue among patients undergoing liver resection for cancer. Surgery 2016;159:1004-1012.

46 Ghaferi AA, Birkmeyer JD, Dimick JB: Hospital volume and failure to rescue with high-risk surgery. Med Care 2011;49:1076-1081.

47 Spolverato G, Ejaz A, Hyder O, et al: Failure to rescue as a source of variation in hospital mortality after hepatic surgery. Br J Surg 2014;101:836-846.

48 Ferraris VA, Bolanos M, Martin JT, Mahan A, Saha SP: Identification of patients with postoperative complications who are at risk for failure to rescue. JAMA Surg 2014;149:1103-1108. 
49 Aiken LH, Sloane DM, Bruyneel DM, Van den Heede K, Griffiths P, Busse R, Diomidous M, Kinnunen J, Kózka M, Lesaffre E, McHugh MD, Moreno-Casbas MT, Rafferty AM, Schwendimann R, Scott PA, Tishelman C, van Achterberg T, Sermeus W; for the RN4CAST consortium: Nurse staffing and education and hospital mortality in nine European countries: a retrospective observational study. Lancet 2014;383:18241830.

50 Pearse RM, Moreno RP, Bauer P, Pelosi P, Metnitz P, Spies C, Vallet B, Vincent JL, Hoeft A, Rhodes A; for the European Surgical Outcomes Study (EuSOS) group for the Trials groups of the European Society of Intensive Care Medicine and the European Society of Anaesthesiology: Mortality after surgery in Europe: a 7-day cohort study. Lancet 2012;380:1059-1065.

51 Maharaj R, Raffaele I, Wendon J: Rapid response systems: a systematic review and meta-analysis. Crit Care 2015; 19:254.

52 Balentine CJ, Naik AD, Robinson CN, et al: Association of high-volume hospitals with greater likelihood of discharge to home following colorectal surgery. JAMA Surg 2014;149:244-251.

53 Breugom AJ, van Dongen DT, Bastiaannet E, Dekker FW, van der Geest LG, Liefers GJ, Marinelli AW, Mesker WE, Portielje JE, Steup WH, Tseng LN, van de Velde CJ, Dekker JW: Association between the most frequent complications after surgery for stage I-III colon cancer and short-term survival, long-term survival and recurrences. Ann Surg Oncol 2016;23:28582865.

54 Tittelbach-Helmrich 1, Abegg U, Wellner F, Makowiec F, Hopt UT, Keck T: Kostenträgerrechnung in der Pankreaschirurgie. Spricht die pekuniäre Betrachtung für eine Zentrenbildung? Chirug 2011;82:105-106.

55 Pronovost PJ, Angus DC, Dorman T, Robinson KA, Dremsizov TT, Young TL: Physician staffing patterns and clinical outcomes in critically ill patients: a systematic review. JAMA 2002;288:2151-2162.

56 Van Leersum NJ, Snijders HS, Henneman D, Kolfschoten NE, Gooiker GA, ten Berge MG, Eddes EH, Wouters MW, Tollenaar RA; on behalf of the Dutch Surgical Colorectal Cancer Audit Group: The Dutch surgical colorectal audit. Eur J Surg Oncol 2013;39: 1063-1070.

57 Arora S, Hull, Hull L, Fitzpatrick M, Sevdalis N, Birnbach DJ: Crisis management on surgical wards: a simulation-based approach to enhancing technical, teamwork, and patient interaction skills. Ann Surg 2015; 261:888-893.

58 Hermanek P, Mansmann U, Staimmer DS, Hermanek $P$ : The German experience: the surgeon as a prognostic factor in colon and rectal cancer surgery. Surg Oncol Clin N Am 2000;9:33-49, vi.
59 de Wilde RF, Besselink MG, van der Tweel I, de Hingh $\mathrm{IH}$, van Eijck CH, Dejong CH, Porte RJ, Gouma DJ, Busch OR, Molenaar IQ: Impact of nationwide centralization of pancreaticoduodenectomy on hospital mortality. Br J Surg 2012;99:404-410.

60 Busweiler LAD, Wijnhoven BPL, van Berge Henegouwen MI, Henneman D, Wouters MWJM, van Hillegersberg R, van Sandick JW; Dutch Upper GI Cancer Audit group: The Dutch Upper GI Cancer Audit: 2011-2014. J Clin Oncol 2016;34(suppl 7S): abstr 309.

61 Leapfrog Group: Factsheet: Evidence-Based Hospital Referral. 2011. www.leapfroggroup.org/media/file/ FactSheet_EBHR.pdf.

62 Khani MH, Smedh K: Centralization of rectal cancer surgery improves long-term survival. Colorectal Dis 2010;12:874-879.

63 Schrag D, Panageas KS, Riedel E, Cramer LD, Guillem JG, Bach PB, Begg CB: Hospital and surgeon procedure volume as predictors of outcome following rectal cancer resection. Ann Surg 2002;236:583-592.

64 Birkmeyer JD, Sun Y, Wong, SL, Stukel TA: Hospital volume and late survival after cancer surgery. Ann Surg 2007;245:777-783.

65 Razenberg LG, Lemmens VE, Verwaal VJ, Punt CJ, Tanis PJ, Creemers GJ, de Hingh IH: Challenging the dogma of colorectal peritoneal metastases as an untreatable condition: results of a population-based study. Eur J Cancer 2016;65:113-120.

66 Morris EJ, Forman D, Tomas JD, Quinke P, Taylor EF, Fairley, Cottier B, Poston G: Surgical management and outcomes of colorectal cancer liver metastases. $\mathrm{Br} \mathrm{J}$ Surg 2010;97:1110-1118.

67 Freys SM, Strube C, Friedemann A, Franke A: Zentrenbildung in der Allgemein- und Viszeralchirurgie. Notwendigkeit oder Trend? Zentralbl Chir 2013;138: 29-32.

68 Bilimoria KY, Phillips JD, Rock CE, Hayman A, Prystowsky JB, Bentrem DJ: Effect of surgeon training, specialization, and experience on outcomes for cancer surgery. A systematic review of the literature. Ann Surg Oncol 2009;16:1799-1808.

69 Hannan EL, Radzyner M, Rubin D, Dougherty J, Brennan MF: The influence of hospital and surgeon volume on in-hospital mortality for colectomy, gastrectomy, and lung lobectomy in patients with cancer. Surgery 2002;131:6-15.

70 Birkmeyer JD, Finks JF, O’Reilly A, Oerline M, Carlin AM, Nunn AR, Dimick J, Banerjee M, Birkmeyer NJ; Michigan Bariatric Surgery Collaborative: Surgical skill and complication rates after bariatric surgery. $\mathrm{N}$ Engl J Med 2013;369:1434-1442.
71 Chowdhury MM, Dagash H, Pierro A: A systematic review of the impact of volume of surgery and specialization on patient outcome. Br J Surg 2007;94:145-161.

72 Sahni NR, Dalton M, Cutler DM, Birkmeyer JD, Chandra A: Surgeon specialization and operative mortality in United States: retrospective analysis. BMJ 2016; 354:i3571.

73 Schweiz: Planung der hochspezialisierten Medizin: Information zum Stand der Umsetzung. Statusbericht zuhanden des Departement des Innern (EDI). Bern, 27.4.2015. www.gdk-cds.ch/fileadmin/docs/public/gdk/ themen/hsm/bt_edi_stand_planung_hsm_20150427_ def_pub_d.pd. http://www.gdk-cds.ch/fileadmin/docs/ public/gdk/themen/hsm/hsm_spitalliste/01a_bb_dc_i oesophagus_def_d.pdf.

74 DGAV - Deutsche Gesellschaft für Allgemein- und Viszeralchirurgie: Ordnung - Das Zertifizierungssystem der DGAV (ZertO 5.1). Berlin, 2016. https://www. dgav.de/fileadmin/media/texte_pdf/zertifizierung/Zertifizierungsordnung_DGAV_5_0.pdf.

75 Haas H, Grifka J, Günther K-P, Heller K-D, Niethard FU, Windhagen H, Ebner M, Mittelmeier W: Endo$\operatorname{Cert}^{\circledR}$. Zertifizierung von Endoprothetischen Versorgungszentren in Deutschland. Stuttgart, Thieme, 2013. https://www.thieme.de/statics/dokumente/thieme/final/ de/dokumente/tw_orthopaedie-u-unfallchirurgie/EndoCert_thieme.pdf.

76 Häusler B: Weißbuch Gelenkersatz. Versorgungssituation bei endoprothetischen Hüft- und Knieeingriffen in Deutschland. 2016. www.iges.com/e6666/e13520/ e14425/e14438/e14439/attr_objs14757/IGES_PK_Gelenkersatz_Praesentation_Haussler_07062016.pdf_ger. pdf.

77 Souza FO, Pereira DV, Santos LH, Antunes L, Chiesa J Gastric cancer patients treated by a general or gastric cancer surgical team: a comparative study. Arq Gastroenterol 2008;45:28-33.

78 Brennan MF: Safety in numbers. Brit J Surg 2004;91: 653-654.

79 de Cruppé W, Ohmann C, Blum K, Geraedts M: Spezialisierung und Mindestmengen - Qualität im Aufwind?; in Rau F, Roeder N, Hensen P (Hrsg): Auswirkungen der deutschen DRG-Einführung. Stuttgart, Kohlhammer, 2009, pp 105-118.

80 Klein A: Wertschätzung und Anerkennung für $\mathrm{Ge}$ sundheitsberufe. Spectrum Urologie 1/2016;8-9.

81 Kant I: Grundlegung zur Metaphysik der Sitten, Vorrede. Erster Abschnitt: Übergang von der gemeinen sittlichen Vernunfterkenntnis zur philosophischen; in Kant I: Werke in zwölf Bänden. Band 7. Frankfurt/M., Suhrkamp, 1977, pp 11-18. www.zeno.org/ Philosophie/M/Kant,+Immanuel/Grundlegung + zur $+M$ etaphysik+der+Sitten/Vorrede. 